\title{
Analisa Perbandingan Performansi Akurasi Mesin CNC (Computer Numerical Control) Router Berbasis Mach3 dan Arduino Uno Menggunakan Metode SQC
}

\author{
Aji Brahma Nugroho, M. A'an Auliq, M.Zulfikar Alrasyid \\ Teknik Elektro, Universitas Muhammadiyah Jember \\ Jl. Karimata 49 Jember 68121 \\ E-mail: alrasyidzulfikar@gmail.com
}

\begin{abstract}
ABSTRAK
Abstrak - Mesin CNC salah satu teknologi yang masih dikembangkan untuk peningkatan kegiatan produksi salah satunya mesin CNC 3 axis dengan fungsi milling. Pada umumnya kontrol utama mesin CNC menggunakan salah satu board dari platform resmi yaitu Mach3 dengan fitur yang sangat mendukung untuk fungsi sebuah mesin CNC salah satunya komunikasi paralel untuk menunjang kinerja mesin CNC tetap stabil, akan tetapi komputer dengan fitur komunikasi paralel umumnya tipe lama dengan spesifikasi rendah yang hanya bisa dijadikan sender dan tidak bisa digunakan untuk mendesain. Berdasarkan permasalahan tersebut maka diperlukan peningkatan efisiensi dalam memanfaatkan teknologi CNC yaitu dengan menggunakan platform yang bersifat open source dan menggunakan komunikasi serial untuk menjadikan teknologi CNC lebih fleksibel dalam hal pengoperasian dengan satu komputer dapat digunakan untuk mendesain dan sender. Arduino Uno salah satu platform yang bersifat open source yang dapat dimanfaatkan untuk menjadi kontrol utama mesin CNC. Hasil penelitian mesin CNC berbasis Arduino menunjukan bahwa penerapan komunikasi serial untuk pengoperasian mesin CNC memiliki perfomansi dan akurasi yang tidak jauh berbeda dengan mesin CNC yang menggunakan komunikasi serial. Dalam parameter jumlah objek yang dikerjakan sama Mach3 30 detik lebih cepat dengan akurasi kesalahan 0,02 mm (0,05\%) dan Arduino 0,04 mm (0,1\%). Dalam parameter jumlah waktu yang sama yaitu 30 menit Mach3 menyelesaikan 8 objek dan objek ke - 9 hanya dikerjakan 25,6\%, Arduino menyelesaikan 8 objek dan objek ke - 9 hanya $14,5 \%$.
\end{abstract}

Kata kunci: CNC, Mach3, Arduino, Milling, Komunikasi serial dan paralel, teknologi produksi.

ABSTRACT

\begin{abstract}
The CNC machines are one of the technologies that are still being developed to increase production activities, one of which is a 3-axis CNC machine with a milling function. In general, the main control of a CNC machine uses one of the boards from the official platform, namely Mach3 with features that are very supportive of the functions of a CNC machine, one of which is parallel communication to support the performance of the CNC machine, but it remains stable, but computers with parallel communication features are generally old type with low specifications. which can only be used as a sender and cannot be used for designing. Based on these problems, it is necessary to increase efficiency in utilizing CNC technology, namely by using a platform that is open source and using serial communication to make $\mathrm{CNC}$ technology more flexible in terms of operation with one computer that can be used for designing and sending. Arduino Uno is an open source platform that can be used as the main control for CNC machines. The results of the research on Arduino-based CNC machines show that the application of serial communication for the operation of $\mathrm{CNC}$ machines has a performance and accuracy that is not much different from CNC machines that use serial communication. In the parameter the number of objects being worked on is Mach3 30 seconds faster with an error accuracy of $0.02 \mathrm{~mm}(0.05 \%)$ and Arduino $0.04 \mathrm{~mm}(0.1 \%)$. In the parameter of the same amount of time, namely 30 minutes Mach3 completed 8 objects and the 9 th object was only done $25.6 \%$, Arduino completed 8 objects and the 9th object was only $14.5 \%$
\end{abstract}

Keywords: CNC, Mach3, Arduino, Milling, Paralel and Serial Communication, Production Technology

Copyright @ 2019 Universitas Muhammadiyah Jember.

\section{PENDAHULUAN}

Komputer tidak hanya digunakan sebagai pengolah data namun juga bisa digunakan dalam pengontrolan suatu peralatan elektronika dengan harapan segala sesuatunya berhasil dengan mudah dan efisien, serta sedikit campur tangan manusia dalam pelaksanaan prosesnya. Salah satu penerapan komputer sebagai pengontrol yaitu untuk mengoperasikan mesin CNC yang pada umumnya 
menggunakan komputer jenis PC. Penggunaan PC dalam mengontrol mesin CNC tentu memiliki kelebihan dan kekurangan dimana kelebihan dari penggunaan PC yaitu dapat memanfaatkan port paralel atau LPT (Line Print Terminal) sebagai komunikasi mesin CNC dengan komputer. Paralel port memiliki kelebihan dalam sebuah komunikasi antara komputer dengan perangkat lain yang dikontrol komputer yaitu dalam satu waktu port paralel dapat mengirim sekaligus menerima data dalam waktu yang bersamaan. Dalam penjelasan singkat ini dapat diketahui bahwa menggunakan paralel port akan mendapatkan data komunikasi yang real time. Beberapa kekurangan penggunaan Mach3 untuk mengontrol mesin CNC yaitu komputer yang mempunyai paralel port umumnya memiliki spesifikasi rendah. Komputer dengan spesifikasi rendah hanya dapat dimanfaatkan menjadi Host/Sender tidak dapat digunakan untuk mendesain. Tentu hal ini akan menambah biaya untuk memenuhi kebutuhan awal dalam pembuatan mesin $\mathrm{CNC}$.

Pengoperasian mesin CNC tidak hanya menggunakan komunnikasi paralel, dengan menggunakan platform lain yaitu mikrokontrol yang dapat dimanfaatkan sebagai kontrol untama mesin CNC menggunakan USB (Universal Serial Bus) tentu lebih fleksibel dalam hal pengoperasian. Penggunaan USB sebagai komunikasi dapat dipastikan menggunakan komputer dengan sepesifikasi yang tinggi tidak jadi masalah, dengan kelebihan yaitu proses Host/Sender dan proses desain dilakukan pada komputer yang sama. Seperti yang diketahui bahwa komunikasi paralel jauh lebih cepat dan realtime jika dibandingkan dengan komunikasi serial. Dalam penelitian akan dilakukan uji coba perbandingan performa dan akurasi mesin CNC dengan platform yang berbeda untuk mengetahui apakah alternatif dalam mengoperasikan mesin CNC dapat direkomendasikan atau tidak. Salah satu mikro kontrol yang bisa menjadi alternatif adalah Arduino, dengan menggunakan mikro kontrol Arduino akan sangat mempermudah dalam pembuatan mesin CNC secara mandiri dan semua aplikasi yang dibutuhkan bersifat open source dengan harga mikrokontrol Arduino terpaut jauh lebih murah jika dibandingkan dengan kontrol CNC menggunakan Mach3.

Mesin CNC yang akan dijadikan penelitian adalah CNC Router dengan fungsi milling. Mesin CNC menggunakan fungsi 3 axis, setiap axis berfungsi sebagai linear aktuator yaitu pada sumbu $\mathrm{X}$ axis, $\mathrm{Y}$ axis, dan $\mathrm{Z}$ axis. Mesin CNC memiliki bagian - bagian yang terdiri dari mekanik, kontrol, sensor batas maksimal dimensi kerja pada mesin yang pada umumnya menggunakan limit switch, serta aplikasi yang digunakan untuk mengoperasikan mesin CNC serta monitoring atau pengawasan kinerja pada mesin CNC. [6]

Apriadi, M Leza (2017),'Perancangan Mesin CNC (Computer Numerical Control) Router dengan Aplikasi GRBL 0.9 Control 3 Axis Sistem X,Y dan Z (Hardware)". Politeknik Negeri Sriwijaya. Kemajuan teknologi dibidang industri, untuk menghasilkan dan menciptakan alat yang lebih berdaya saing tinggi dari sebelumnya untuk memperoleh peningkatan hasil produksi. Hal ini dibutuhkan pembelajaran dan penelitian agar suatu proses pembuatan alat yang telah ada dapat dilakukan dengan baik dan lancar. Dengan membandingkan beberapa hal dan menganalisa bagaimana kelebihannya dan kekurangannya dalam hal ini dapat memadukan segala kelebihan yang ada pada beberapa kemungkinan yang dibuat menjadi satu. [1]

Alfarisi, Adli (2017),"Analisis Pengendalian Kualitas Produk Ornamen Desain Interior Dengan Metode Ststistical Quality Control Pada Mesin CNC (Computer Numerical Control)". Universitas Jember. Teknologi industri berkembang pesat terlebih pada era sekarang dan sangat diperlukan untuk memenuhi peningkatan kebutuhan konsumen dan dibidang teknologi itu sendiri. Semakin meningkatnya pengetahuan konsumen, tuntutan terhadap variasi dan mutu olahan juga semakin meningkat. Oleh karena itu, perlu adanya pengenalan dan inovasi teknologi produksi menggunakan mesin CNC untuk peningkatan mutu produk. [2]

Mikrokontrol Arduino Uno yang dimanfaatkan akan ditingkatkan dengan upgrade firmware GRBL1.1 dan driver motor stepper menggunakan TB6600, dimana peneliti sebelumnya masih menggunakan GRBL 9.0 dan driver motor A4988. Beberapa kelebihan menggunakan mikro kontrol Arduino adalah dapat dioperasikan menggunakan laptop dengan berbagai versi windows atau komputer dengan syarat minimal CPU pentium 4 dengan kapasitas ram $512 \mathrm{MB}$ atau yang lebih tinggi, karena mikro kontrol Arduino menggunakan komunikasi serial yang lebih fleksibel dalam mengoperasikan 
mesin CNC. Untuk peningkatan firmware GRBL1.1 memiliki kelebihan pada salah satu fitur yang akan dimanfaatkan yaitu auto home machine, mesin dapat menentukan titik zero pada X-axis dan Y-axis secara otomatis. Penggunaan driver motor stepper TB6600 akan mempermudah dalam pengaturan step pulse sesuai dengan tipe motor yang akan digunakan dan pemilihan arus yang akan dikonsumsi oleh motor stepper. Menentukan kebutuhan yang sesuai dengan tipe motor stepper yang digunakan, dilakukan dengan mengatur 6 saklar dan mengikuti data tabel yang tertera pada driver motor stepper TB600. Dengan menggunakan pengaturan yang dapat dipastikan nilainya maka akan menambah kinerja pada motor stepper serta memudahkan pengawasan.

\section{KAJIAN PUSTAKA}

Berikut adalah beberapa penelitian terkait yang sudah dilakukan sebelumnya:

2.1. Perancangan Mesin CNC (Computer Numerical Control) Router dengan Aplikasi GRBL 0.9 Control 3 Axis Sistem X,Y dan Z (Hardware). Apriadi, M Leza. 2017. Politeknik Negeri Sriwijaya.

Pada penelitian ini terdapat beberapa pokok pembahasan penelitian yang memiliki aspek dari segi rancang bangun mesin, sistem mekanik penggerak dengan akurasi yang tinggi, cara kerja motor penggerak, memodifikasi perangkat keras motor stepper dan driver motor supaya dapat dihubungkan dengan control board GRBL 0.9 .

Pada rancang bangun mesin, kerangka mesin dibangun dari beberapa bahan yaitu, alumuniun profile, stainless berbentuk tabung berfungsi sebagai linear aktuator dan bracket dengan bahan PLA untuk spindle router.

Pengendalian gerak motor secara bertahap untuk mendapatkan akurasi pada setiap step gerakan linear aktuator. Dalam proses ini dibutuhkan tahap kalibrasi untuk memastikan mesin bergerak dengan jarak yang sesuai. Tahapan selanjutnya akan diketahui tingkat akurasi pada mesin jika dilakukan perbandingan antara perhitungan dengan pengukuran.

Cara kerja motor stepper sebagai penggerak utama pada mesin (X-axis, Y-axis, Z-axis) yaitu berotasi sebanyak 200 step, dimana setiap step memiliki nilai sudut $1,8^{\circ}$ sehingga memungkinkan memberikan gerak dengan akurasi tinggi.

Pada driver motor stepper menggunakan A4988 dan terhubung dengan arduino. Pengaturan kebutuhan arus pada driver motor A4988 menggunakan trim resistor yang ada pada driver, sehingga dibutuhkan ketelitian dalam proses menyetel arus yang akan digunakan, karena jika arus terlalu besar maka motor akan menjadi cepat panas, dan jika arus terlalu kecil maka motor akan kehilangan torsi.

Pada arduino harus dilakukan instal driver khusus yang berfungsi sebagai media komunikasi arduino dengan komputer. Firmware cnc yang digunakan adalah grbl 0.9 yang nantinya menjadi platform dasar untuk pengoperasian mesin cnc berbasis arduino. Aplikasi yang digunakan untuk mengirim dan memonitoring gcode adalah grbl control.

Besarnya langkah bervariasi antara $0,9^{\circ}$ hingga $90^{\circ}$ dapat dikendali secara open loop dan tidak memerlukan feedback dari sensor posisi sesuai untuk mengoperasikan CNC Router.

2.2. Proses Produksi Prototipe Mesin CNC Router 3-axis. Zoro Zulfikar. 2017. Universitas Riau.

Pada penelitian ini menjelaskan rancang bangun mesin cnc 3 axis (X-axis, Y-axis, Z-axis) berupa prototipe dengan fungsi router untuk kebutuhan UKM (Usaha Kecil dan Menengah) yang pada mulanya setiap produk kerajinan dikerjakan secara manual yang membutuhkan waktu cukup lama dan tingkat akurasi dari hasil pengerjaan sangat kecil. Tentu hal ini sangat tidak efisien dalam proses produksi, maka dilakukan pengembangan dengan membuat prototipe mesin cnc 3 axis dengan harga yang cukup murah dan mudah dijangkau oleh kalangan pelaku UKM untuk meningkatkan efisiensi produksi dan meningkatkan daya saing yang tinggi.

Konsep rancang bangun pada penelitian ini yaitu dengan proses pembuatan mesin cnc 3 axis secara mandiri atau DIY (Do It Yourslef) untuk pembuatan kerangka pada mesin cnc 3 axis, dan ditunjang dengan beberapa bahan yang sudah ada dipasaran untuk mempermudah proses pembuatan seperti stainless steel grade 201, linear aktuator dan lead screw.

Komponen elektronik dirancang sedemikian rupa untuk menunjang kinerja maksimal pada mesin, pemilihan komponen disesuaikan dengan kebutuhan prototipe mesin cnc 3 axis, beberapa komponen utama yang dibutuhkan dalam perakitan mesin cnc 3 axis diantara lain sebagai berikut : motor stepper, motor driver, Mach3 board, power supply, limit switch, Spindle kit.

Motor stepper yang digunakan adalah tipe nema 17 dengan nilai sudut pada rotasi setiap step $1,8^{\circ}$ dengan total satu rotasi 200 step, motor stepper dipilih karena memiliki ketelitian yang cukup 
tinggi jika dipasangkan dengan lead srew. Motor driver yang digunakan adalah tipe TB6560 dengan kapasitas 5A berfungsi untuk menghubungkan mach3 board dengan aktuator dan memperkuat sinyal pada aktuator sehingga memaksimalkan fungsinya. Driver TB6560 memiliki fitur untuk dapat menentukan arus dan step yang dipilih dengan cara mengatur saklar yang penggunaanya mengikuti aturan tabel yang sudah tersedia pada driver sehingga memungkinkan pengguna dengan mudah mengatur kebutuhan sesuai yang diinginkan.

Mach3 board adalah kontroler yang digunakan sebagai penghubung antara komputer dengan aktuator berupa sinyal input atau output. Software yang digunakan yaitu mach3 berfungsi untuk melakukan pemrosesan dan pemantauan mesin cnc 3 axis. Komunikasi yang digunakan mach3 board yaitu DB25 atau komunikasi paralel yang memiliki kelebihan dalam kecepatan komunikasi karena komunikasi paralel dapat mengirimkan sinyal data sekaligus menerima sinyal data dalam waktu yang bersamaan sehingga dapat dipastikan tingkat akurasi secara komunikasi.

Power supply merupakan penyedia utama daya tegangan dc untuk driver motor, motor stepper, dan spindle. Power supply berfungsi merubah tegangan ac $220 \mathrm{v}$ menjadi tegangan dc yang stabil untuk menjaga kinerja dari mesin cnc 3 axis.

Limit switch merupakan komponen yang dilengkapi dengan katup yang berfungsi sebagai push button. Limit switch adalah salah satu jenis sensor mekanis yang memanfaatkan fungsi push button untuk memberikan sinyal data yang akan dimanfaatkan dengan fungsi tertentu.

Spindle kit berfungsi sebagai mata router atau berfungsi sebagai pahat pada mesin cnc 3 axis yang akan dimanfaatkan untuk melakukan proses pahat dengan pengaturan tertentu sehingga menghasilkan sebuah produk baru dengan efisiensi produksi karena tidak menggunakan tenaga manusia.

2.3. Rancang Bangun CNC Mini Router 3 Axis Berbasis Mikrokontroler Arduino. Mukhlis Sukmajaya. 2019. UNIVERSITAS BANGKA BELITUNG

Pada penelitian ini memaparkan rancang bangun mesin cnc mini router 3 axis berbasis arduino untuk menunjang para pengerajin kreatif dengan latar belakang seniman, penghobi seni, dan pelajar kesenian dalam lingkup seni ukir/pahat kayu. Pada umumnya para pengerajin seni ukir kayu menggunakan alat konvensional karena harga jual mesin cnc relatif mahal.

Komposisi mesin cnc mini router 3 axis meliputi kerangka mesin yang dirancang sesuai kebutuhan penelitian, sistem transmisi atau komunikasi antara komputer dengan mesin cnc dengan perantara mikrokontroler arduino, dan sistem kendali yaitu komputer yang digunakan untuk membuat desain dan mengoperasikan mesin cnc. Mesin cnc yang sudah dirancang akan dilakukan uji untuk memastikan tingkat akurasi mesin dalam melakukan proses pembuatan produk.

Bahan uji yang digunakan berupa kayu yang telah diukur dan diperhitungkan kekuatannya kemudian disesuaikan dengan kemampuan mesin cnc untuk menghindari kerusakan pada bahan atau mata pahat pada mesin cnc. Didapat tekanan geser 292,6 Mpa dan pada kayu 72,70 Mpa, diketahui motor stepper mampu melakukan proses pahat pada bahan kayu. Variasi kecepatan router adalah $400 \mathrm{rpm}, 700 \mathrm{rpm}$, dan $1000 \mathrm{rpm}$, laju kecepatan pahat bervariasi yaitu $50 \mathrm{~mm} / \mathrm{menit}$, $100 \mathrm{~mm} / \mathrm{menit}$, dan $150 \mathrm{~mm} / \mathrm{menit}$. Nilai rata - rata akurasi terendah bernilai $29,70 \mathrm{~mm}$ dengan akurasi $99 \%$ didapat pada kecepatan router $1000 \mathrm{rpm}$ dengan kecepatan pahat $150 \mathrm{~mm} / \mathrm{menit}$, rata rata akurasi tertinggi bernilai 30,00 dengan presisi $100 \%$ didapat pada pada kecepatan router 1000rpm dengan kecepatan pahat 50mm/menit. Akurasi mesin pada beberapa hasil uji yaitu $99,4 \%$ dengan nilai kesalahan $0,23 \mathrm{~mm}$.

2.4. Rancang Bangun CNC Mini Router 3 Axis untuk Keperluan Praktikum CAD/CAM. Gatot Eka Pramono. Universitas Ibn Khaldun Bogor

Penelitian ini ditujukan untuk meningkatkan sebuah kegiatan praktikum yang dilakukan di lingkup akademis khususnya pendidikan teknik/sekolah kejuruan hingga pendidikan tingkat lanjut. Seperti yang diketahui bahwa harga mesin cnc mini yang memenuhi standart operasional masih relatif mahal dengan kisaran harga diatas 30juta, sehingga tidak semua instansi pendidikan mampu untuk melakukan pengadaan fasilitas penunjang untuk kegiatan pendidikan dibidang teknik.

Penelitian ini dilakukan untuk memberikan sebuah alternatif untuk menunjang kegiatan praktikum dengan cara melakukan penelitian rancang bangun mesin cnc 3 axis dengan mandiri. Langkah - langkah yang akan dilakukan yaitu dengan mempersiapkan beberapa hal diantaranya desain rancang bangun mesin cnc 3axis, perhitungan daya router, perhitungan defleksi poros, dan menguji kinerja mesin cnc mini router 3 axis.

Rancang bangun mesin cnc 3 axis terbuat dari bahan kayu mahoni sebagai rangka utama/tumpuan untuk menyatukan semua bagian mesin cnc. Sistem penggerak menggunakan lead screw/sekrup ulir yang dipasangkan kopling dengan motor stepper untuk transmisi penggerak 
setiap axis/sumbu. Linear aktuator menggunakan poros yang dipasangkan dengan linear bearing yang terhubung dengan bracket setiap sumbu beserta ball screw.

Perangkat keras kontroler yang digunakan yaitu mach3 board yang berfungsi menghubungkan komputer dengan sistem aktuator pada mesin cnc. Mach3 menggunakan sistem komunikasi paralel dengan port DB25 yang memungkinkan untuk melakukan dua proses (input/output) dalam satu waktu, sehingga dapat dipastikan tingkat akurasi pengiriman/penerimaan data. Penggunaan aplikasi yang diterapkan adalah solidwork untuk pembuatan desain dua dimensi maupun tiga dimensi sebagai proyeksi dari perancangan mesin cnc mini serta mensimulasikan linear aktuator pada mesin cnc 3 axis.

Hasil penelitian menunjukan bahwa kemampuan router untuk dapat memotong segala jenis kayu membutuhkan daya 336watt dengan torsi yang dihasilkan 0,0211Nm dan kecepatan minimal putaran $15924 \mathrm{rpm}$, ukuran diameter pahat $6 \mathrm{~mm}$. Defleksi maksimal poros $20 \mathrm{~kg}$ pada sumbu $\mathrm{x}$ $0,48 \mathrm{~mm}$ dan pada sumbu y $0,041 \mathrm{~mm}$. Akurasi sumbu $\mathrm{x}$ dan sumbu $0,2 \mathrm{~mm}$ dengan hasil pahat pada sumbu $\mathrm{x}$ menghasilkan objek kerja yang cembung dengan nilai maksimum $0,5 \mathrm{~mm}$. Sedangkan hasil pahat pada sumbu y menghasilkan objek kerja yang cekung dengan nilai maksimum $0,08 \mathrm{~mm}$. Defleksi alat pada sumbu $\mathrm{x}$ dan dengan beban $5 \mathrm{~kg}$ adalah $2 \mathrm{~mm}$ sedangkan pada sumbu y adalah $1,2 \mathrm{~mm}$.

\section{METODE PENELITIAN}

Tujuan analisa perbandingan yang dilakukan antara mesin CNC berbasis Mach3 dan berbasis Arduino Uno untuk mengetahui apakah Arduino Uno layak untuk dijadikan kontrol mesin CNC yang dimanfaatkan pada suatu badan usaha atau industri menengah.

\subsection{Diagram Blok Sistem}

Blok diagram akan menjelaskan secara singkat cara kerja sistem kontrol mesin CNC berbasis Arduino UNO. Laptop yang difungsikan sebagai host memiliki fungsi input dan output, input yang dimaksud adalah menerima data pada sensor Proximity untuk ditampilkan (output) sebagai alarm jika mesin bergerak melebihi batas maksimal bidang kerja. File g-code adalah hasil dari pengaturan sebuah desain yang dirubah menjadi kode untuk diproses Arduino Uno dan mengirim sinyal pulsa pada motor untuk bergerak sesuai perintah dari g-code yang kemudian menghasilkan output dengan gerakan mesin CNC 3 axis dan mengaktifkan sistem limit pada mesin.

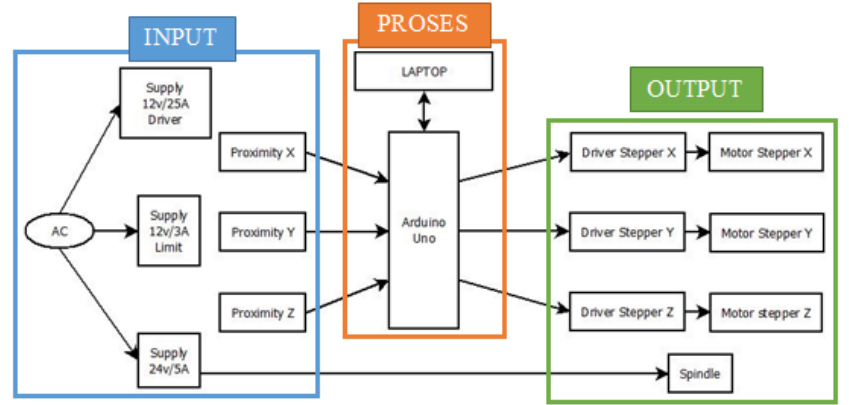

Gambar 1. Diagram Blok Sistem

\subsection{Diagram Operasional Mesin}

Pengoperasian mesin CNC membutuhkan beberapa Software yang digunakan untuk membuat desain yang akan dikerjakan dan desain masih diproses untuk dijadikan vektor kemudian setiap vektor akan ditentukan prosesnya sesuai kebutuhan. Setiap vektor akan diproses dengan pemilihan mata pahat yang akan digunakan serta teknik pahat seperti apa yang akan diproses. 


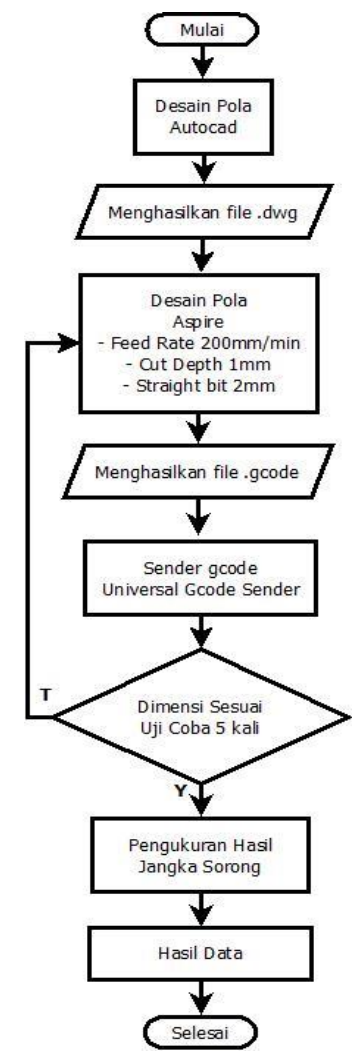

Gambar 2. Diagram Operasional Mesin

\subsection{Diagram Pengambilan Data}

Proses analisis yang dilakukan dalam penelitian ini menggunakan pendekatan Statistic Quality Control (SQC) untuk pengendalian produk. Dalam SQC terdapat tujuh alat bantu (seven tools) untuk membantu memecahkan permasalahan yaitu lembar periksa (check sheet), histogram, stratifikasi, diagram pencar, diagram pareto, diagam sebab akibat (fishbone) dan grafik kendali. Pada penelitian ini tidak menggunakan semua tools yang ada pada SQC, hanya digunakan jenis tools yang sesuai dangan kondisi permasalahan yang akan dipecahkan yaitu diagram sebab akibat (fishbone diagram) dan peta kendali. Untuk mempermudah mengolah data hasil penelitian ini digunakan Software Microsoft office excel.

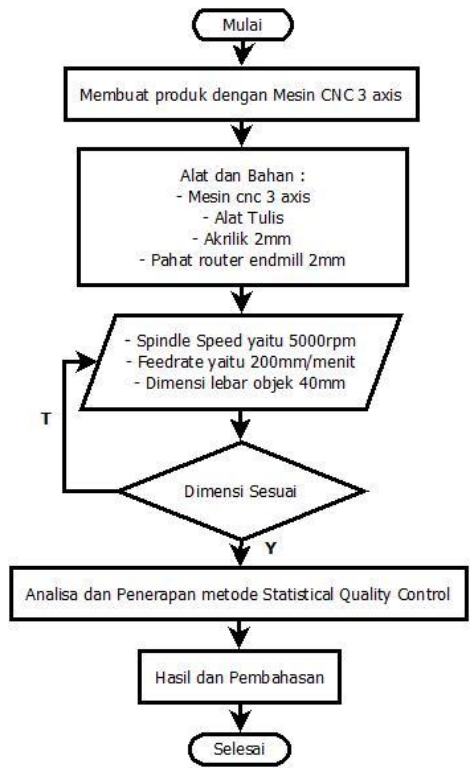

Gambar 3. Diagram Pengambilan Data 


\subsection{Perancangan Objek Uji}

Objek yang akan menjadi bahan penelitian adalah objek yang tidak mudah berubah kualitas secara kepadatan serta ukuran yang tidak berubah terhadap perubahan suhu dan kelembapan serta kelembaman. Bahan yang akan dijadikan objek uji adalah akrilik dengan ketebalan $2 \mathrm{~mm}$ karena mudah dalam pengendalian kualitas. Berikut adalah spesifikasi bahan objek akrilik $2 \mathrm{~mm}$ :

Tabel 1. Objek Uji

\begin{tabular}{cccll}
\hline No & Objek Bahan Uji & Bentuk & \multicolumn{1}{c}{$\begin{array}{c}\text { Parameter } \\
(\mathbf{m m})\end{array}$} & \multicolumn{1}{c}{ Keterangan } \\
\hline 1 & Akrilik & Persegi & Tebal $=2$ & Diproses potong dengan \\
& & & $\mathrm{P}=40$ & cara milling \\
& & & $\mathrm{L}=40$ & \\
\hline
\end{tabular}

\section{HASIL DAN PEMBAHASAN}

\subsection{Pengujian Proximity Induktif}

Pengujian sensor Proximity dilakukan untuk memastikan sensor akan mendeteksi limit maksimal pada bidang kerja sehingga tidak merusak fungsi mekanik ketika desain yang dibuat tidak sesuai dengan kapasitas ukuran mesin. Sensor akan mendeteksi jika bracket axis berjarak $4 \mathrm{~mm}$ dari unjung sensor maka secara otomatis mesin akan berhenti dan memberi peringatan bahwa pergerakan axis sudah mencapai batas maksimum.

Tabel 2. Pengujian Proximity Induktif

\begin{tabular}{ccccc}
\hline No & Axis Mesin & $\begin{array}{c}\text { Pembacaan jarak } \\
(\mathbf{m m})\end{array}$ & Alarm & Keterangan \\
\hline 1 & $\mathrm{X}+$ & 2 & ON & Berhasil \\
2 & $\mathrm{X}-$ & 2 & ON & Berhasil \\
3 & $\mathrm{Y}+$ & 2 & ON & Berhasil \\
4 & $\mathrm{Y}-$ & 2 & ON & Berhasil \\
5 & $\mathrm{Z}+$ & 2 & ON & Berhasil \\
6 & $\mathrm{Z}-$ & 2 & ON & Berhasil \\
\hline
\end{tabular}
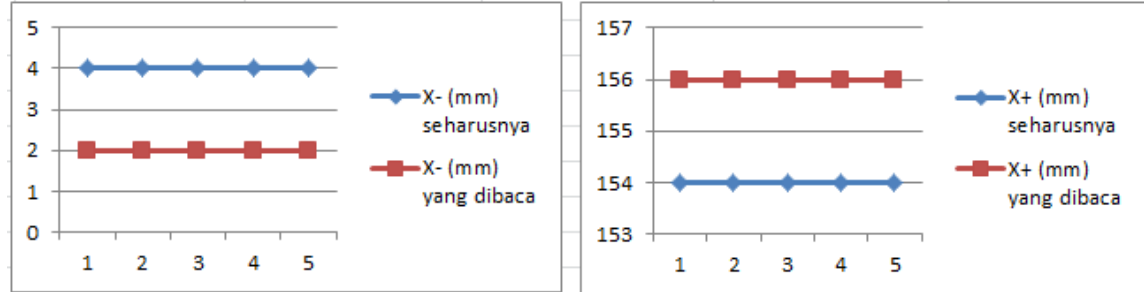

Gambar 4. Grafik Pengujian Pada X axis
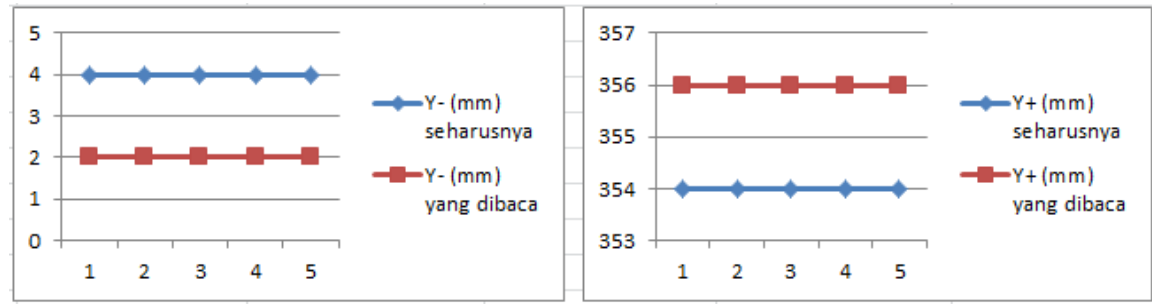

Gambar 5. Grafik Pengujian Pada Y axis 

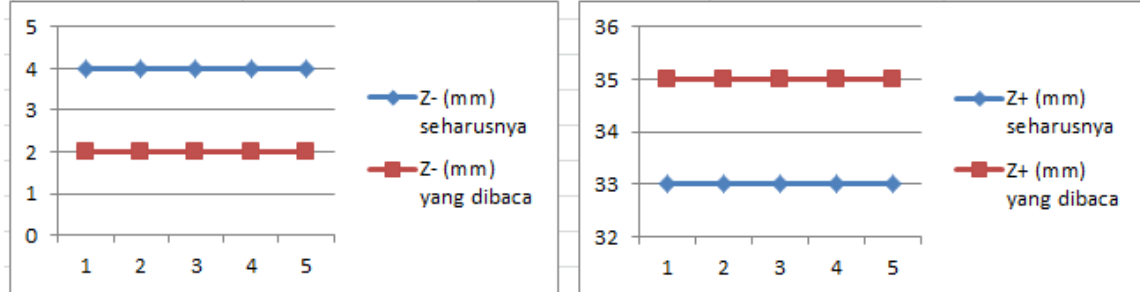

Gambar 6. Grafik Pengujian Pada Z axis

\subsection{Pengujian Berdasarkan Jumlah Produk yang Sama}

Pengujian akurasi objek dari proses pengerjaan mesin CNC berbasis Mach3 dan Arduino Uno dilakukan dengan perlakuan jumlah yang dikerjakan sama untuk mengetahui perbedaan waktu ketika proses produksi.

Tabel 3. Hasil Perhitungan Mach3

\begin{tabular}{crcrl}
\hline No & $\overline{\boldsymbol{X}} \boldsymbol{i}(\mathbf{m m})$ & Ket. & Si $(\mathbf{m m})$ & Waktu \\
\hline 1 & 39,8875 & TRUE & 0,021794495 & \\
2 & 39,875 & TRUE & 0,01 & \\
3 & 39,8075 & TRUE & 0,025980762 & \\
4 & 39,7775 & TRUE & 0,008660254 & \\
5 & 39,8025 & TRUE & 0,205121915 & \\
6 & 39,7425 & TRUE & 0,066895441 & \\
7 & 39,7925 & TRUE & 0,087607077 & 36 Menit 20 Detik \\
8 & 39,99 & FALSE & 0,280356915 & \\
9 & 39,875 & TRUE & 0,060827625 & \\
10 & 39,91 & TRUE & 0,054772256 & \\
CLx & 39,846 & CLs & 0,082201674 & \\
UCLx & 39,9798243 & UCLs & 0,186268993 & \\
LCLx & 39,7121757 & LCLs & 0 & \\
\hline
\end{tabular}

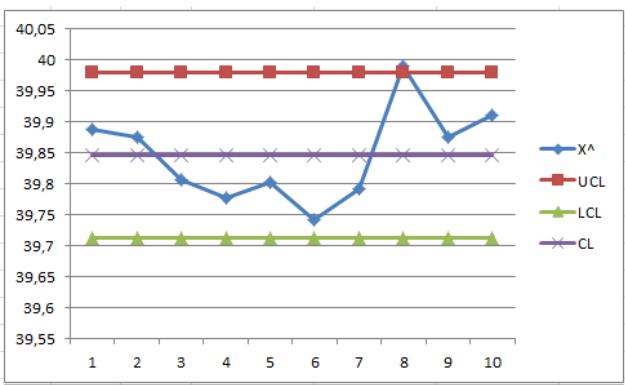

Gambar 7. Grafik Peta Kendali X Mach3

Tabel 4. Hasil Perhitungan Arduino Uno

\begin{tabular}{crcrl}
\hline No & $\overline{\boldsymbol{X}} \boldsymbol{i}(\mathbf{m m})$ & Ket. & Si $(\mathbf{m m})$ & Waktu \\
\hline 1 & 39,82 & TRUE & 0,15033296 & \\
2 & 39,905 & TRUE & 0,03316625 & \\
3 & 40,1 & FALSE & 0,07874008 & \\
4 & 39,815 & TRUE & 0,11445523 & \\
5 & 39,9275 & TRUE & 0,03278719 & \\
6 & 39,9025 & TRUE & 0,09526279 & \\
7 & 39,9075 & TRUE & 0,0753326 & 36 menit 50 Detik \\
8 & 39,9525 & TRUE & 0,26509432 & \\
9 & 39,9125 & TRUE & 0,02598076 & \\
10 & 39,925 & TRUE & 0,07 & \\
CLx & 39,91675 & CLs & 0,09411522 & \\
UCLx & 40,0699696 & UCLs & 0,21326509 & \\
LCLx & 39,7635304 & LCLs & 0 & \\
\end{tabular}




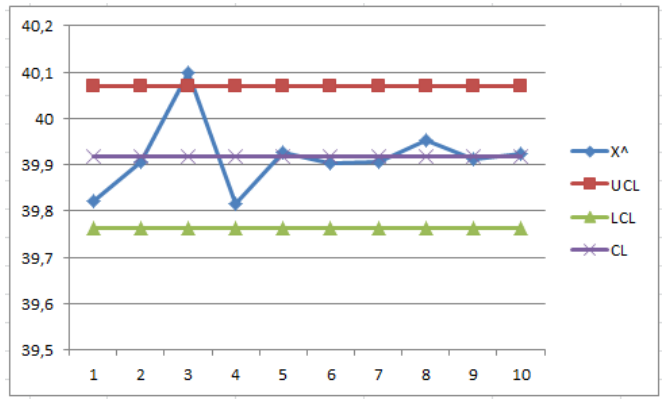

Gambar 8. Grafik Peta Kendali X Arduino Uno

\subsection{Pengujian Berdasarkan Jumlah Waktu Sama}

Pengujian akurasi objek dari proses pengerjaan mesin CNC berbasis Mach3 dan Arduino Uno dilakukan dengan perlakuan lama waktu yang dibutuhkan sama untuk mengetahui jumlah produk yang diproduksi.

Tabel 5. Hasil Pengukuran Objek Mach3

\begin{tabular}{|c|c|c|c|c|c|c|c|c|c|c|c|}
\hline \multirow[t]{2}{*}{$\mathbf{X i}$} & \multirow[t]{2}{*}{ Bentuk } & \multirow{2}{*}{$\begin{array}{l}\text { Waktu } \\
\text { Proses } \\
\text { (Menit) }\end{array}$} & \multicolumn{4}{|c|}{$\begin{array}{c}\begin{array}{c}\text { Parameter Dimensi } \\
(\mathbf{m m})\end{array} \\
\text { Subgrup (ni) } \\
\end{array}$} & \multicolumn{4}{|c|}{$\begin{array}{l}\text { Hasil Ukur (mm) } \\
\text { Subgrup (ni) }\end{array}$} & \multirow[t]{2}{*}{$\begin{array}{c}\text { Keterangan } \\
(\%)\end{array}$} \\
\hline & & & n1 & n2 & n3 & n4 & n1 & $\mathrm{n} 2$ & n3 & n4 & \\
\hline $\mathrm{x} 1$ & Persegi & \multirow{9}{*}{$\begin{array}{c}30 \\
\text { Menit }\end{array}$} & 40 & 40 & 40 & 40 & 39,86 & 39,88 & 39,90 & 39,92 & $100 \%$ \\
\hline $\mathrm{x} 2$ & Persegi & & 40 & 40 & 40 & 40 & 39,79 & 39,81 & 39,82 & 39,80 & $100 \%$ \\
\hline $\mathrm{x} 3$ & Persegi & & 40 & 40 & 40 & 40 & 39,85 & 39,89 & 39,85 & 39,82 & $100 \%$ \\
\hline $\mathrm{x} 4$ & Persegi & & 40 & 40 & 40 & 40 & 40,12 & 40,09 & 39,90 & 39,91 & $100 \%$ \\
\hline$x 5$ & Persegi & & 40 & 40 & 40 & 40 & 39,92 & 39,94 & 39,87 & 39,85 & $100 \%$ \\
\hline$x 6$ & Persegi & & 40 & 40 & 40 & 40 & 39,89 & 39,88 & 39,79 & 39,80 & $100 \%$ \\
\hline$x 7$ & Persegi & & 40 & 40 & 40 & 40 & 39,89 & 39,89 & 39,88 & 39,86 & $100 \%$ \\
\hline$x 8$ & Persegi & & 40 & 40 & 40 & 40 & 39,84 & 39,86 & 39,75 & 39,77 & $100 \%$ \\
\hline $\mathrm{x} 9$ & Persegi & & 40 & 40 & 40 & 40 & 39,95 & 40,05 & 1,92 & 0 & $25,6 \%$ \\
\hline
\end{tabular}

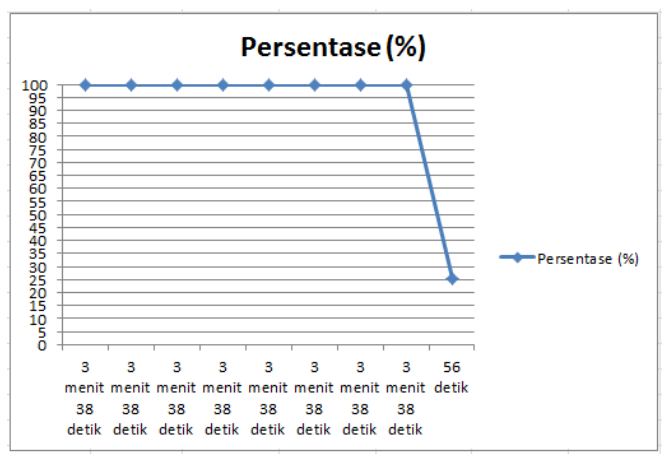

Gambar 9. Grafik Persentase Objek Mach3

Tabel 6. Hasil Pengukuran Objek Arduino

\begin{tabular}{|c|c|c|c|c|c|c|c|c|c|c|c|}
\hline \multirow[t]{2}{*}{$\mathbf{X i}$} & \multirow[t]{2}{*}{ Bentuk } & \multirow{2}{*}{$\begin{array}{l}\text { Waktu } \\
\text { Proses } \\
\text { (Menit) }\end{array}$} & \multicolumn{4}{|c|}{$\begin{array}{c}\text { Parameter Dimensi } \\
(\mathbf{m m}) \\
\text { Subgrup (ni) }\end{array}$} & \multicolumn{4}{|c|}{$\begin{array}{l}\text { Hasil Ukur (mm) } \\
\text { Subgrup (ni) }\end{array}$} & \multirow[t]{2}{*}{$\begin{array}{c}\text { Keterangan } \\
(\%)\end{array}$} \\
\hline & & & n1 & n2 & n3 & n4 & n1 & n2 & n3 & n4 & \\
\hline $\mathrm{x} 1$ & Persegi & & 40 & 40 & 40 & 40 & 39,90 & 39,92 & 39,93 & 39,96 & $100 \%$ \\
\hline $\mathrm{x} 2$ & Persegi & & 40 & 40 & 40 & 40 & 39,80 & 39,79 & 39,82 & 39,83 & $100 \%$ \\
\hline $\mathrm{x} 3$ & Persegi & & 40 & 40 & 40 & 40 & 39,79 & 39,82 & 39,83 & 39,84 & $100 \%$ \\
\hline $\mathrm{x} 4$ & Persegi & & 40 & 40 & 40 & 40 & 40,15 & 40,10 & 39,95 & 39,97 & $100 \%$ \\
\hline$\times 5$ & Persegi & 30 Menit & 40 & 40 & 40 & 40 & 39,94 & 39,96 & 39,83 & 39,85 & $100 \%$ \\
\hline$x 6$ & Persegi & & 40 & 40 & 40 & 40 & 39,85 & 39,83 & 39,79 & 39,78 & $100 \%$ \\
\hline$\times 7$ & Persegi & & 40 & 40 & 40 & 40 & 39,85 & 39,88 & 39,77 & 39,75 & $100 \%$ \\
\hline $\mathrm{x} 8$ & Persegi & & 40 & 40 & 40 & 40 & 39,80 & 39,85 & 39,87 & 39,85 & $100 \%$ \\
\hline$\times 9$ & Persegi & & 40 & 40 & 40 & 40 & 39,85 & 6,55 & 0 & 0 & $14,5 \%$ \\
\hline
\end{tabular}




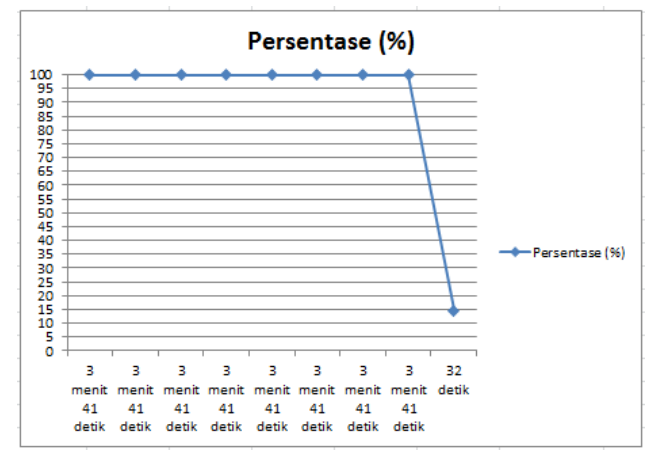

\subsection{Diagram Sebab - Akibat (fishbone diagram)}

Gambar 10. Grafik Persentase Objek Arduino

Diagram sebab-akibat/fishbone diagram berfungsi sebagai analisa dari beberapa faktor yang menjadikan kerusakan pada produk. Faktor yang menjadikan pengaruh serta penyebab produk rusak diantaranya adalah :

- Manusia(Human Error)

- Mesin/tools

\section{- Bahan baku/pokok}

Tujuan pengendalian kualitas untuk menjaga produk sesuai dengan standart yang telah ditentukan. Kualitas produk dapat terpengaruh ketika proses produksi berlangsung. Oleh karena itu pengendalian kualitas sangat diperlukan ketika proses produksi dilakukan.

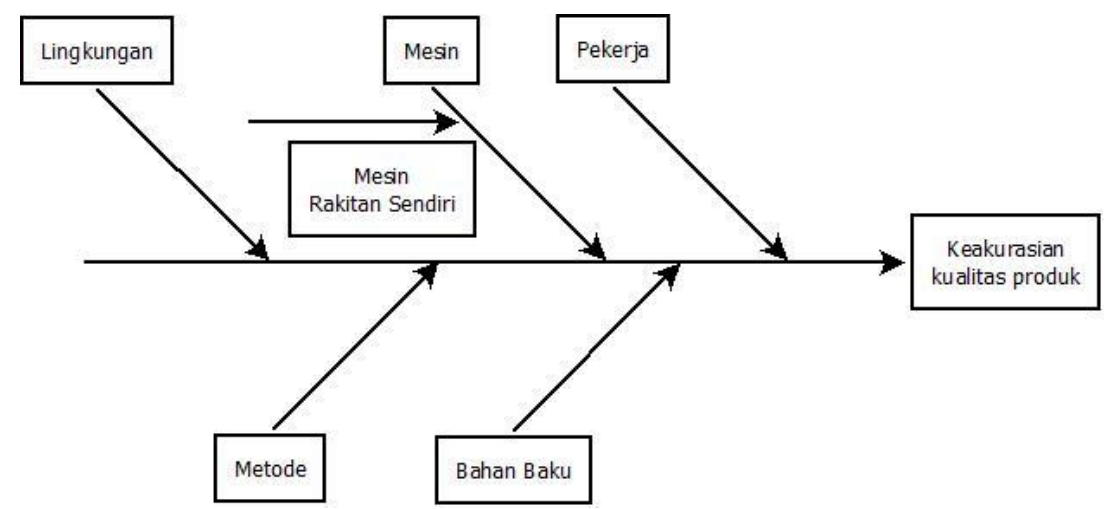

Gambar 11. Diagram Sebab Akibat

\section{KESIMPULAN}

1. Pengambilan data dilakukan berdasarkan perlakuan pada mesin adalah memproduksi objek dengan jumlah yang sama dan memiliki waktu pengerjaan yang berbeda, kinerja mesin CNC Berbasis Mach3 adalah $90 \%$ dari 10 produk yang diuji hanya 1 yang cacat dengan persentase kerusakan 0,05\%, kinerja mesin CNC Berbasis Arduino Uno adalah $90 \%$ dari 10 produk yang diuji hanya 1 yang cacat dengan persentase kerusakan $0,1 \%$. Selisih waktu pengerjaan secara total hanya 30 detik dimana setiap pengerjaan objek selisih waktunya hanya 3 detik dari jumlah total waktu pada Mach3 36 menit 20 detik dan Arduino Uno 36 menit 50 detik.

2. Pengambilan data dilakukan berdasarkan perlakuan pada mesin adalah memproduksi objek dengan lama waktu yang sama dan memiliki jumlah produksi yang sama dengan hasil objek yang terakhir/objek ke-9 memiliki proposi hasil yang berbeda, pada mesin CNC berbasis Mach3 objek ke9 telah memproses sebanyak 25,6\% dan pada mesin CNC berbasis Arduino Uno objek ke-9 telah memproses sebanyak $14,5 \%$.

3. Setelah melakukan analisi sebab akibat, diketahui salah satu faktor penyebab terjadinya perubahan ukuran pada setiap objek dengan nilai yang kecil yaitu mesin CNC yang digunakan bukan buatan pabrik melainkan DIY (Do It Yourself). Hasil analisa dengan penggunaan metode Statistic Quality 
Control (SQC) mesin CNC berbasis Arduino tidak memiliki tingkat kesalahan signifikan meskipun dalam waktu pengerjaan dan jumlah produksi Mach3 lebih unggu karena menggunakan komunikasi paralel dan Arduino uno menggunakan komunikasi Serial. Penelitian ini membuktikan bahwa Arduino Uno layak untuk dijadikan sebagai alternatif kontrol utama dalam pembuatan mesin CNC.

\section{REFERENSI}

[1] Apriadi, M Leza. 2017. "Perancangan Mesin CNC (Computer Numerical Control) Router Dengan Aplikasi GRBL 0.9 Control 3 Axis Sistem X,Y dan Z (Hardware)". Politeknik Negeri Sriwijaya.

[2] Alfarisi, Adli. 2017."Analisis Pengendalian Kualitas Produk Ornamen Desain Interior Dengan Metode Ststistical Quality Control Pada Mesin CNC (Computer Numerical Control)". Universitas Jember.

[3] M Ade Riawan. 2018. "Rancang Bangun CNC Router Kayu Dengan Menggunakan Control Mach3". Politeknik Perkapalan Negeri Surabya.

[4] M.Bhavani. 2017. "Design and Implementation of CNC Router". Chennai, Tamil nadu, India.

[5] Roni Permana Saputra. 2011. "Desain dan Implementasi Sistem Kendali CNC Router Menggunakan PC untuk Flame Cutting Machine". Universitas Gadjah Mada.

[6] Sigit Widiyanto .2017. "Rancang Bangun Training KIT CNC MILL 3 AXIS Sebagai Materi Praktek CADCAM di STT Duta Bangsa". STT Duta Bangsa.

[7] Zoro Zulfikar ${ }^{1}$.2017. "Proses Produksi Prototipe Mesin CNC Router 3-axis". Universitas Riau.

[8] Nina Hairiyah, Raden Rizki Amalia, Eva Luliyanti. 2019.“Analisis Statistical Quality Control (SQC) pada Produksi Roti di Aremania Bakery”. State Polytechnic of Tanah Laut. 


\section{BIOGRAFI PENULIS}

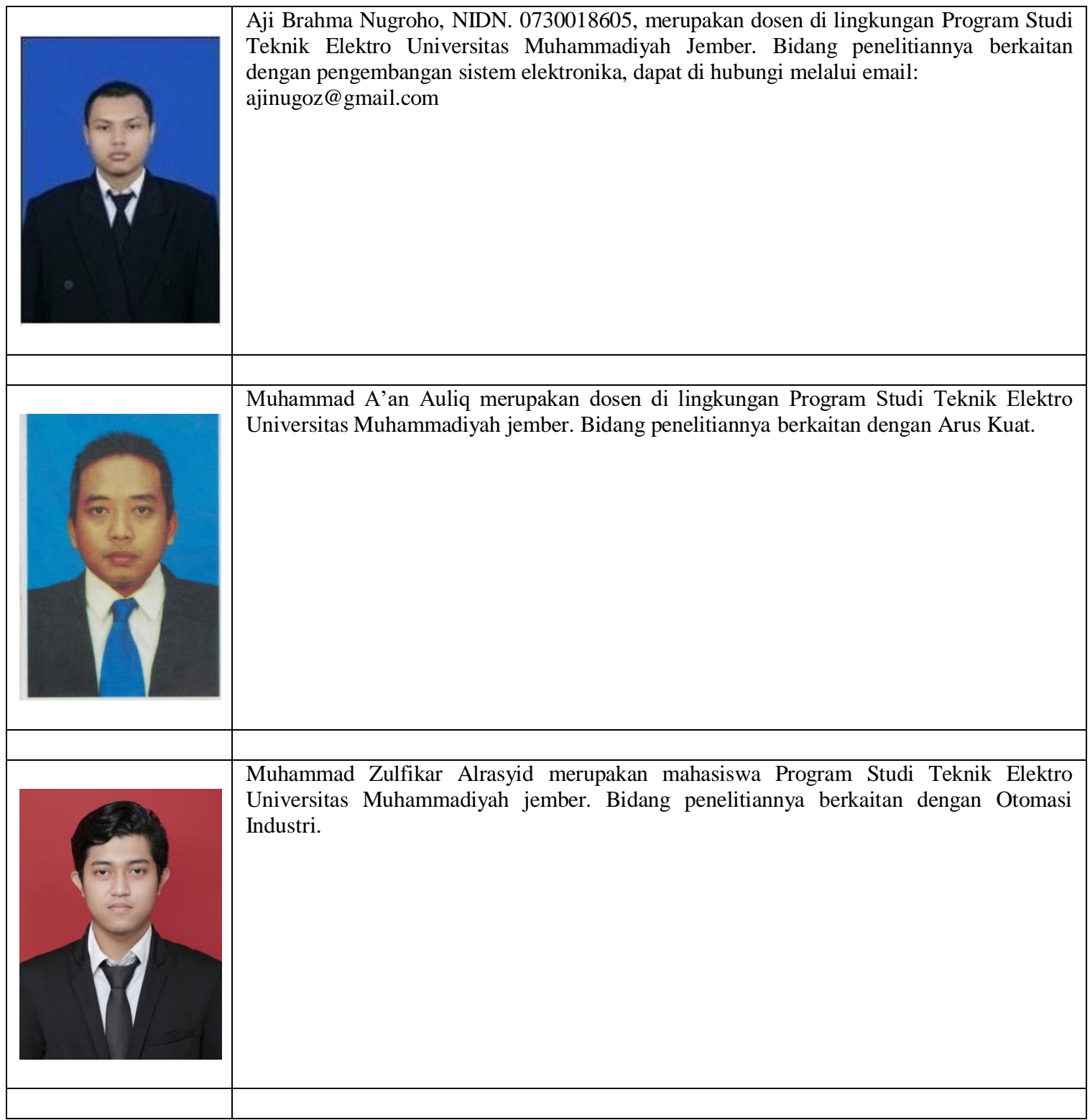

